\title{
POKROKY V HEPATOLOGII - SX-ELLA STENT DANIS ${ }^{1}$
}

\author{
Dagmar Adámková Korbuthová \\ 8: $200-435,2006$ \\ ISSN $1212-4117$ \\ Jihočeská univerzita $\mathrm{v}$ Českých Budějovicích, Zdravotně sociální fakulta, katedra sociální práce \\ a sociální politiky
}

Cirhóza jater je velmi časté onemocnění, které je způsobeno požíváním většího a pravidelného množství alkoholu (alkoholismus), hepatitidou typu B a C, autoimunitní hepatopatií, Wilsonovou nemocí, zrrídka i polékovou hepatopatií atd. Kolem $5 \%$ populace poživá pravidelně větší množství alkoholu, a proto patř́ do rizikové skupiny. Zde je však nutno uvést tzv. „cirhogenní dávku“ - tedy množství alkoholu, které je nutné $\mathrm{v}$ př́ípadě pravidelného požívání alkoholu k rozvoji jaterní cirhózy. $\mathrm{Na}$ základě posledních výzkumů jsou uváděny tyto údaje. Jestliže denní dávka přesáhne u ženy 20-40 g alkoholu a u muže $60 \mathrm{~g}$, dá se již hovořit o alkoholismu. Pro představivost, uvedené údaje o alkoholu znamenají následující ( $20 \mathrm{~g}$ je jako $1 / 21$ piva nebo $1 / 41$ vína). Avšak ne u každého pijana se musí nutně jaterní cirhóza rozvinout.

Zhruba asi 30 let po zavedení očkování proti hepatitidě typu $\mathrm{B}$ je stále přeočkovanost velmi nízká (méně než $30 \%$ ) a očkovací látka proti hepatitidě typu $\mathrm{C}$ bude $\mathrm{s}$ největší pravděpodobností až po roce 2011. Zhruba 25-30 let bude incidence cirhózy jater stoupat.

Nejzávažnější a život ohrožující akutní komplikace u cirhózy jater je krvácení z jícnových varixů. I když je mortalita při prvním akutním krvácení do $5 \%$, další epizody krvácení u stejného pacienta znamenají nárůst mortality o 40-60 \%. U nyní používaných metod (endoskopická intervence, farmakologické terapie) lze akutní krvácení z jícnových varixů zastavit asi u $80 \%$ prípadů. Zbylých $20 \%$ umírá na následky vykrvácení.

Ke zvládnutí krvácení z jícnových varixů byl vypracován v nemocnici AKH Linz úplně nový způsob léčby. Základem je okamžité zvládnutí krvácení z jícnových varixů pomocí samoexpandovatelného kovového stentu, potahovaného polyuretanem. Tento SX-ELLA Stent Danis se nachází ve složeném stavu v tzv. zavaděči. Zavaděč je zkonstruován tak, že umožňuje přesnou pozici implantovaného stentu $\mathrm{v}$ jícnu, bez pomoci endoskopie nebo RTG. Po uvolnění stentu ze zavaděče se stent samovolně roztáhne a zevnitř jícnu způsobí kompresi varixů, které se nacházejí pod sliznicí jícnu. Tím, že roztažený stent je průchodný, umožňuje pacientovi bez problémů polykat sliny, okamžitě přijímat tekutou a později polotuhou stravu. Jícnový stent zůstává po dobu jednoho týdne zaveden, což je dostatečně dlouhá doba na to, aby se provedla kompletní diagnostika a stabilizování pacienta $\mathrm{k}$ definitivní léčbě. Během tohoto týdne se provádí morfologická diagnostika, CT, splenoportografie (prováděná MPI technologií a třírozměrové rekonstrukce rečiště plnícího jícnové varixy). Po uplynutí jednoho týdne je pacient dostatečně stabilizován a pristupuje se $\mathrm{k}$ definitivní terapii.

$\mathrm{V}$ nemocnici AKH Linz kromě běžně zaváděných TIPSSu (umělá objî̌z’ka krevního oběhu jater) se provádí také ojedinělý druh operace, jedná se o azygoportální dekonexe (přerušení cév, které plní jícnové varixy). Tato operace byla také vyvinuta na chirurgickém oddělení AKH Linz pod vedením Doz. OA. Dr. Danise. V současné době se ve světě provádí pouze na čtyřech pracovištích. Tato operace patři mezi tzv. minimálně invazivní výkony a operační zátěž je oproti běžné operaci zanedbatelná. Tato operace se provádí s cílem snížit $\mathrm{v}$ krvi množství močoviny, které způsobuje trvalé poškozování mozku s následnou encefalopatií (poškození mozku), jež se však může prohloubit až do samotného bezvědomí.

Cílem všech těchto opatření je překlenout interval do transplantace jater (aktivní alkoholik není vhodným kandidátem) bez dalších akutních krvácejících příhod. Zatímco tato opatření nevyléčí jaterní cirhózu, transplantace jater je dosud ,jedinou“ metodou, která tuto nemoc dokáže vyléčit. Dalo by se říci, že každý pacient s krvácejícími varixy je z medicínského hlediska 
„potenciálním kandidátem transplantace jater“. Zabráněním dalších krvácejících epizod umožní $\mathrm{v}$ prŕpadě dobré spolupráce pacienta s lékařem prodloužení intervalu po selhání jater a zabezpečí dobrou kvalitu života.

Závěrem možno říci, že kolektiv lékařŭ, techniků a ošetrujujícího personálu pod vedením Doz. OA. Dr. Danise provedl zásadní zlepšení péče o pacienty s jícnovými varixy vývojem stentu, vypracováním metodiky laparoskopické operace (azygoportální dekonexe) a využíváním moderních zobrazujících metod jako je CT, MRI a splenoportografie.

Vysvětlivka k článku:

1. od 01.12.2005 byl udělen Certifikát CE

Výsledky provedených výkonů 2003-2005

\begin{tabular}{|l|c|}
\hline Vyšetření MRI + CT & 104 \\
\hline TIPSS & 42 \\
\hline SX-ELLA Stent Danis & 30 \\
\hline Azygoportální dekonexe & 26 \\
\hline
\end{tabular}

Dagmar Adámková Korbuthová a.dagmar@email.cz 